\title{
A new paradigm of genetic testing for hereditary breast/ovarian cancers
}

\author{
Ava Kwong *, JW Chen, Vivian Y Shin
}

\section{A B S T R A C T}

Introduction: Genetic risk factors and family history play an important role in breast cancer development. This review aimed to summarise the current genetic testing approach to hereditary breast/ovarian cancer.

Methods: A systematic literature review was performed by searching the PubMed database. Publications available online until January 2015 that addressed issues related to hereditary breast/ovarian cancer genetic counselling/testing were selected. The search terms used were "familial breast/ovarian cancer", "susceptibility genes", "genetic counselling", and "genetic testing". The data extracted for this review were analysed by the authors, with a focus on genetic testing for hereditary breast/ovarian cancer.

Results: Although a greater proportion of inherited breast/ovarian cancers are due to the BRCA1 and $B R C A 2$ mutations, a number of new genes have emerged as susceptibility candidates, including rare germline mutations in high penetrance genes, such as TP53 and PTEN, and more frequent mutations in moderate/low penetrance genes, such as $P A L B 2$, $C H E K 2$ and ATM. Multi-gene testing, if used appropriately, is generally a more cost- and time- effective method than single-gene testing, and may increase the number of patients who can be offered personal surveillance, risk-reduction options, and testing of high-risk family members.

Conclusions: Recent advances in molecular genetics testing have identified a number of susceptibility genes related to hereditary breast and/or ovarian cancers other than BRCA1 and BRCA2. The introduction of multi-gene testing for hereditary cancer has revolutionised the clinical management of high-risk patients and their families. Individuals with hereditary breast/ovarian cancer will benefit from genetic counselling/testing.

\section{Hong Kong Med J 2016;22:171-7}

DOI: $10.12809 / \mathrm{hkmj} 154634$

A Kwong *, FRCS (Edin), PhD

JW Chen, PhD

VY Shin, PhD

Breast Surgery Division, The University of Hong Kong, Pokfulam, Hong Kong

* Corresponding author: akwong@asiabreastregistry.com

\section{Introduction}

Breast cancer is one of the most common cancers and the second most common leading cause of cancer-related death among women with 1.67 million new cases diagnosed in 2012 (25\% of all cancers). ${ }^{1}$ About $39 \%$ of these new cases are found in Asia. ${ }^{1}$ In the US, women have a $12 \%$ lifetime risk of developing breast cancer including women of young age. In addition, approximately 1 in 250 women in their 30s will develop breast cancer in the next 10 years. ${ }^{2}$ Assessment of an individual's risk for breast cancer is complex, and based on different aspects such as personal lifestyle, environmental exposure, reproductive influences, and drug use. Genetic risk factors and family history, however, also play important roles in breast cancer development. Only $5 \%$ to $10 \%$ of breast cancer cases are characterised as hereditary and follow the autosomal dominant pattern of transmission. ${ }^{3}$ On the other hand, $15 \%$ to $20 \%$ of breast cancer cases are familial, referring to women who have two or more first- or seconddegree relatives with the disease. ${ }^{4-6}$ Hereditary cancers follow a Mendelian inheritance pattern and tend to have an earlier age of onset. Familial cancers do not follow a specific inheritance pattern. Defects in the BRCA1 and BRCA2 genes are the most wellknown high-risk factors among inherited breast cancers. Results from genome-wide association studies have broadened our knowledge over the last few years about the specific genes that contribute to familial breast cancer. Other genes such as TP53 and PTEN have also been identified to be associated with an increased risk of breast cancer. ${ }^{7}$ High-risk women are likely to benefit from genetic testing as there are now emerging targeted therapies and interventions that have been shown to improve outcome in mutation carriers.

\section{Methods}

A search of the medical literature was performed to identify the relevant studies and reviews on genetic testing for hereditary breast/ovarian cancer. The PubMed database was searched for publications available online until January 2015 that address the related issues; "familial breast/ovarian cancer", "susceptibility genes", "genetic counselling", and 


\section{遺傳性乳腺癌/卵巢癌的新一代基因檢測 櫎靄慧、陳嘉偉、冼念慈}

引言：遺傳風險因素和家族史是乳癌發病的關鍵因素。本文概括目前 針對遺傳性乳腺癌/卵巢癌的基因檢測方法。

方法：通過PubMed數據庫搜索直至2015年1月為止所有有關遺傳 性乳腺癌/卵巢癌和基因諮詢/檢測的文章。用以搜索文獻的關鍵詞 為「家族性乳腺癌/卵巢癌」(familial breast/ovarian cancer)

$\ulcorner$ 易感基因」（susceptibility genes）、「遺傳諮詢」（genetic counselling）和 $\ulcorner$ 基因檢測」（genetic testing）。針對遺傳性乳腺 癌/卵巢癌的基因檢測，筆者把搜索到的文章作重點分析。

結果：縱使大多數遺傳性乳腺癌/卵巢癌均由 $B R C A 1$ 和 $B R C A 2$ 基因突 變引起, 另一些新的易感基因也逐漸被認為是這種癌症的關聯基因, 包括具有高外顯率如TP53和PTEN的罕見突變基因, 以及具有中/低 外顯率如PALB2、CHEK2和ATM的常見突變基因。一般來説, 如使 用得當, 多基因檢測組合較單基因檢測省時及更具成本效益, 令更多 基因檢測呈陽性的患者得到個人監測、更多降低風險的選擇, 以及替 高風險的家族成員作檢測。

結論：分子遺傳學測試的最新發展讓我們確定除了 $B R C A 1$ 和 $B R C A 2$ 基因突變, 還有其他引致遺傳性乳腺癌/卵巢癌的易感基因。引入多基 因檢測組合對於高風險患者和其家族成員的臨床管理來説起了革命性 的作用。遺傳性乳腺癌/卵巢癌患者將受惠於遺傳諮詢/檢測。

"genetic testing" were used as the search terms.

\section{High-penetrance genes $B R C A 1$ and $B R C A 2$}

Hereditary breast and ovarian cancer syndrome (HBOC) refers to a germline mutation in either the $B R C A 1$ or $B R C A 2$ gene, and individuals who carry a mutation have an increased risk of developing cancers. BRCA1 and BRCA2 are tumour-suppressor genes that code for proteins that help repair damaged DNA and therefore play vital roles in securing the stability of the cell's genetic material. Defects in these two genes may result in protein with malfunction, thus DNA damage may not be repaired properly. As a result, cells are prone to develop genetic mutations leading to cancer development. Scientists discovered in the 1990s that BRCA1 and BRCA2 are breast cancer susceptibility genes. ${ }^{8,9}$ Women have a $57 \%$ to $60 \%$ and $49 \%$ to $55 \%$ lifetime risk of developing breast cancer if they carry a BRCA1 or BRCA2 mutation, respectively. ${ }^{10,11}$ Women with mutations in the BRCA1 cancer susceptibility gene associated with HBOC have a $39 \%$ to $46 \%$ risk of developing ovarian cancer by the age of 70 years while approximately $10 \%$ to $27 \% B R C A 2$-positive women are at risk. ${ }^{12-14}$ The result of genetic testing for the $B R C A$ mutation is important to decisions made about management of breast cancer. For example, a woman diagnosed with breast cancer and who harbours the BRCA1 or BRCA2 mutation has a greater risk of developing a second breast cancer in the contralateral breast, and this risk is age-related. Women diagnosed with breast cancer at a younger age have a higher risk of developing contralateral malignancy compared with those diagnosed at an older age. ${ }^{15}$ BRCA1 mutation carriers tend to have more triple-negative breast cancer (TNBC), medullary histopathology, somatic TP53 mutations, higher histological grade, and present at a younger age compared with women with sporadic breast cancers. Basal markers such as cytokeratin (CK14, CK5/6, CK17), osteonectin, and EGFR are more commonly expressed in BRCA1positive tumours than in control tumours unselected for mutation status. ${ }^{16-18}$ The National Comprehensive Cancer Network (NCCN) annually updates guidelines with respect to genetic counselling and testing (www.nccn.org) and the most updated guidelines recommend it for individuals who meet the HBOC testing criteria. Guidelines are based on young age of onset, family history of breast cancer, specific histological types of breast cancer (TNBC), ovarian (epithelial and peritoneal), and prostate cancer (Gleason score $\geq 7$ ). For details refer to NCCN guidelines (Genetic/Familial High-Risk Assessment: Breast and Ovarian), version 1.2016. ${ }^{19}$

Knowing the mutation status of germline $B R C A 1$ and $B R C A 2$, patients may be offered alternative screening and/or therapeutic interventions (Table $1^{19}$ ), including intensive breast surveillance (magnetic resonance imaging [MRI] of the breasts in addition to standard breast imaging such as mammography and ultrasonography), mastectomy instead of breast conservation surgery, prophylactic mastectomy and salpingo-opherectomy, or the prescription of chemopreventive drugs and more recently the choice of chemotherapy as primary treatment, for example, carboplatin. A recent study has shown that treatment with carboplatin produces no advantage over docetaxel in patients with TNBC, although those with $B R C A 1$ or $B R C A 2$ mutation benefited from either drug. ${ }^{20} \mathrm{~A}$ number of targeted therapies, such as poly(ADP-ribose) polymerase inhibitors, have been shown to be effective in $B R C A$ mutation carriers. ${ }^{21,22}$ The evolution of sequencing technologies enables parallel testing of multiple genes, leading to simultaneous analysis of breast cancer predisposition genes with either high or intermediate penetration. Multi-gene panel testing, however, has raised new issues regarding patient eligibility for gene testing other than BRCA1 and $B R C A 2$, and more importantly, interpretation of genetic results.

\section{TP53}

One of the high penetrance genes is TP53, which is a tumour-suppressor gene that encodes the transcription factor protein $p 53$. It is a ubiquitous 
TABLE I. NCCN management of the hereditary breast and/or ovarian cancer syndrome ${ }^{19}$ (Adapted from the NCCN guidelines, version 1.2016)

\begin{tabular}{|c|c|}
\hline $\begin{array}{l}\text { Management of hereditary breast and/or } \\
\text { ovarian cancer syndrome }\end{array}$ & Details \\
\hline Breast screening & $\begin{array}{l}\text { Annual breast MRI screening or mammogram for age } 25-29 \text { years. Breast MRI screening and } \\
\text { mammogram for age } \geq 35-70 \text { years. Individual consideration for age }>70 \text { years }\end{array}$ \\
\hline Risk-reducing mastectomy & $\begin{array}{l}\text { Counselling may include a discussion regarding degree of protection, reconstruction options, and } \\
\text { risks }\end{array}$ \\
\hline $\begin{array}{l}\text { Risk-reducing salpingo-oophorectomy is } \\
\text { recommended for those aged } 35-40 \text { years } \\
\text { and upon completion of child bearing }\end{array}$ & $\begin{array}{l}\text { Counselling may include a discussion of reproductive wishes, extent of cancer risk, degree of } \\
\text { protection for breast and ovarian cancer, and management of menopausal symptoms }\end{array}$ \\
\hline $\begin{array}{l}\text { Address the psychosocial, social, and } \\
\text { quality-of-life aspects }\end{array}$ & $\begin{array}{l}\text { For those who have not selected risk-reducing salpingo-oophorectomy, consider concurrent } \\
\text { transvaginal ultrasound and CA-125 monitoring starting at } 30 \text { years or 5-10 years before the } \\
\text { earliest age of first diagnosis of ovarian cancer in the family }\end{array}$ \\
\hline $\begin{array}{l}\text { Consider chemoprevention for breast cancer } \\
\text { and ovarian cancer }\end{array}$ & - \\
\hline $\begin{array}{l}\text { Consider investigational imaging and } \\
\text { screening studies }\end{array}$ & - \\
\hline
\end{tabular}

Abbreviations: $\mathrm{MRI}=$ magnetic resonance imaging; $\mathrm{NCCN}=$ National Comprehensive Cancer Network

protein implicated in preservation of an intact genome. It regulates cell cycle, DNA repair, apoptosis, cellular senescence, and metabolism. It has been shown to be involved in various kinds of cancer progression such as osteosarcomas, colon cancer, and lung cancer. ${ }^{23-28} \mathrm{Li}$-Fraumeni syndrome (LFS) is a rare but highly penetrance familial cancer syndrome that is characterised by germline TP53 mutations inherited in an autosomal dominant manner, in which $60 \%$ to $80 \%$ of LFS families carry a mutant $T P 53 .{ }^{29}$ In addition to soft-tissue sarcomas and osteosarcomas, LFS families are likely to exhibit a pattern of earlyonset and multiple primary cancers including breast, brain, and adrenocortical tumours ${ }^{29,30}$; LFS is thought to account for approximately $1 \%$ of all breast cancers. $^{31,32}$ Approximately 1\% of women diagnosed with breast cancer before the age of 40 years carry a TP53 mutation. ${ }^{32}$ Breast cancer is the most frequent malignancy among female TP53 mutation carriers and accounts for up to one third of all cancers in LFS families. ${ }^{33}$ Although LFS is only responsible for a tiny fraction of breast cancers, women with LFS have a breast cancer risk of $56 \%$ by the age of 45 years and greater than $90 \%$ by the age of 60 years, and LFS accounts for a 60 -fold increased risk for early-onset breast cancer compared with the general population. ${ }^{34,35}$ Women with LFS-related breast cancer are reported to have very early disease onset $(20 \mathrm{~s}$ or $30 \mathrm{~s})$ and a relatively advanced disease staging. ${ }^{36-38}$ Studies have shown that $3 \%$ to $8 \%$ of women who are diagnosed with breast cancer younger than 30 years without a significant family history of cancer have TP53 mutation..$^{31,39,40}$ The NCCN has included early-onset breast cancer as one of the criteria for offering TP53 genetic testing, regardless of the family history of cancer. TP53 mutations can be tested either through sequencing the entire encoding region that identifies approximately $95 \%$ of TP53 mutations or just selected regions. Analysis of hot-spot regions located in exons 4-9 can detect approximately $90 \%$ of all TP53 mutations. ${ }^{19,41,42}$ When the TP53 mutation is present in an individual, breast screening and preventive guidelines are similar to those for $B R C A$ mutation carriers. In addition, a full-body MRI scan is an option as a screening tool. Individuals with the following should be included for genetic testing of TP53 ${ }^{19}$ : early-onset breast cancer ( $\leq 35$ years), a combination of diagnosis of a sarcoma at the age of $<45$ years, AND a first-degree relative diagnosed at the age of $<45$ years with cancer, multiple cancers (brain tumours, sarcomas, and leukaemia).

\section{PTEN}

PTEN is a phosphatase tensin homologue located on chromosome $10 \mathrm{q} 23.3$ that plays a tumoursuppressive role due to its PI3K (phosphatidylinositol3-kinase) phosphatase activity. Abnormal PTEN cannot activate cell cycle arrest and apoptosis and leads to uncontrolled cell survival. ${ }^{43}$ Germline PTEN mutations have been identified in a variety of disorders such as Cowden syndrome (CS) or PTEN hamartoma tumour syndrome. Affected individuals have multiple hamartomas in a variety of tissues with an increased risk of malignant transformation. ${ }^{44}$ Breast cancer is the most common tumour associated with CS. Although CS is responsible for $<1 \%$ of all breast cancers, women with this syndrome have a $25 \%$ to $50 \%$ risk of developing breast cancer in a lifetime and are prone to early onset. ${ }^{45,46}$ The frequency of multifocal and bilateral disease is increased in CS-associated breast cancers compared with sporadic cases. ${ }^{47,48}$ 
Women with CS also have an increased risk (67\%) of benign breast disease characterised by mammary hamartomas that can be multiple and bilateral. ${ }^{49}$ Similar to TP53 mutation carriers, PTEN mutation carriers are advised to have breast surveillance and interventions as recommended for $B R C A$ mutation carriers. The testing criteria for CS are those who present with breast cancer, endometrial cancer, follicular thyroid cancer, multiple gastrointestinal hamartomas, ganglioneuromas, or other diseases including macrocephaly, macular pigmentation of glans penis, and mucocutaneous lesions. ${ }^{19}$

\section{Moderate- and low-penetrance genes}

PALB2

PALB2 (partner and localiser of BRCA2) is involved in homologous recombination and double-strand break repair along with $B R C A 2 . .^{50,51}$ Loss-of-function mutations are associated with a 2 to 4 times higher risk than non-mutation carriers for familial breast cancer. $^{52-54}$ A study analysed the risk of breast cancer among 362 members of 154 families who had deleterious PALB2 mutations. ${ }^{55}$ The results revealed that the risk of having breast cancer for female $P A L B 2$ mutation carriers was 8 to 9 times higher among those younger than 40 years, 6 to 8 times higher among those 40 to 60 years, and 5 times higher among those $>60$ years when compared with the general population. The estimated cumulative risk of breast cancer among female mutation carriers increased from $14 \%$ to $35 \%$ from the age of 50 to 70 years. In addition, the risk of breast cancer for $P A L B 2$ mutation carriers was significantly increased by familial factor. ${ }^{56}$ Thus, it has been advised that $P A L B 2$ mutation testing should be performed routinely to identify mutations in $\mathrm{HBOC}$ families since it may be of clinical relevance. This is increasingly being tested.

\section{Other hereditary breast cancer susceptibility genes}

There are other low-penetrance genes that are associated with hereditary breast cancer such as STK11, CDH1, and $M M R$ genes, and that are responsible for Peutz-Jeghers syndrome, hereditary diffuse gastric cancer syndrome, and Lynch syndrome, respectively. ${ }^{57-59}$ Some moderatepenetrance genes such as CHEK2, ATM, BRIP1, RAD51C, RAD51D, BARD1, MRE11, RAD50, NBS1, and $F A N C M$ have been recognised as breast cancer susceptibility genes. ${ }^{60}$

The recent development of multi-gene testing for hereditary cancer has had a great impact on the clinical management and genetic counselling of high-risk patients and their families. The decision to use multi-gene testing should be no different than the rationale for testing a single gene. Multigene testing is more cost-effective than sequentially testing multiple genes associated with a phenotype. For example, young women diagnosed with breast cancer can be tested for mutations in BRCA1, $B R C A 2$, and TP53. Detailed testing criteria for genes can be found in NCCN guidelines version $1.2016 .{ }^{19}$ Next-generation sequencing enables simultaneous analysis of a specific panel of genes, but there are limited outcome data on clinical interventions, particularly in lower-penetrance-gene-mutationrelated breast cancers. Results of a multi-gene panel may pose difficulty in interpretation and clinical decisions. At present, multi-gene testing is largely performed for research purposes. There are limited data regarding the degree of cancer risk associated with some of the genes on the recurrent multi-gene test. There is a lack of well-established guidelines for risk management for carriers of mutations in some of the genes, which may lead to extra surveillance and surgeries.

Nonetheless multi-gene testing is more costeffective and time-effective than single-gene testing, and provides a higher mutation detection rate. It may reduce the number of high-risk families with negative results of finding a gene mutation due to the increased coverage. The lifetime breast cancer risk estimates associated with gene mutations are listed in Table $2 .^{10,13,36,56,58,61-74}$

In Hong Kong, breast cancer is the most common cancer in the female population. The Hong Kong Hereditary Breast Cancer Family Registry was established in 2007. It functions as a data registry of hereditary breast, ovarian and prostate cancer families and is also an established charitable organisation that subsidises the cost of genetic testing for underprivileged individuals. More than 1900 patients with breast and/or ovarian cancer who satisfied the selection criteria have received genetic testing in Hong Kong. Each individual underwent thorough genetic counselling to ensure the implications of genetic testing were understood.

TABLE 2. Estimated lifetime risk of breast cancer associated with selected susceptibility genes ${ }^{10,13,36,56,58,61-74}$

\begin{tabular}{lc}
\hline Gene & Estimated lifetime risk of breast cancer \\
\hline BRCA1 & $55-65 \%^{10}$ \\
BRCA2 & $45-47 \%^{13}$ \\
TP53 & $49-60 \%^{36}$ \\
PTEN & $25-50 \%^{61,62}$ \\
PALB2 & $33-58 \%^{56}$ \\
STK11 & $30-50 \%^{58,63,64}$ \\
CDH1 & $39-52 \%^{65,66}$ \\
ATM & $15-52 \%{ }^{67-70}$ \\
CHEK2 & $20-44 \%{ }^{71-74}$ \\
\hline
\end{tabular}


Around 600 probands were screened for $B R C A 1$ and BRCA2 mutations by bi-directional Sanger sequencing of all coding exons and multiplex ligationdependent probe amplification. ${ }^{75}$ The sensitivity of identifying mutations is comparable with the goldstandard method with good bioinformatics support. Next-generation sequencing meets rigorous quality standards and can provide clinical sequencing results that are equivalent to those obtained from Sanger DNA sequencing analysis. ${ }^{76}$ We started employing next-generation DNA sequencing to expedite analysis workflow and expand the gene panel in 2011 to include TP53 and PTEN for sequencing. Cases with a negative result after screening with our in-house developed gene panel are further sequenced using 454 GS Junior System (Roche Life Sciences) or MiSeq (Illumina). Sequencing data are analysed by an in-house fully developed automatic bioinformatics pipeline. The mutation screening result of a 4-gene panel $B R C A 1, B R C A 2, T P 53$, and $P T E N$ in our recruited patients revealed that $9 \%$ carried such mutations. Nonetheless a number of clinically high-risk patients have tested negative for the above genes. This indicates that there is further potential in expanding the coverage to different lower-penetrance genes such as $P A L B 2$, which has recently been reported to be important to cause hereditary breast cancer in our testing strategy. ${ }^{56}$

\section{Conclusions}

Clinical assessment of an individual's risk of hereditary cancer is based on the evaluation of family history, age of onset, and type of cancer. Advances in molecular genetics testing have identified a number of genes associated with inherited susceptibility to breast and/or ovarian cancers such as BRCA1, $B R C A 2, P T E N$, and TP53. The recent introduction of next-generation sequencing technology and multi-gene panel testing for hereditary cancer has rapidly altered the clinical approach to high-risk patients and their families. Although there are still limitations, individuals with hereditary or familial breast/ovarian cancer are likely to benefit from strategies including prevention, screening, and targeted treatment. Suitable patients and families should be offered genetic counselling and testing.

\section{Acknowledgements}

This study was supported by The Hong Kong Hereditary Breast Cancer Family Registry, Hong Kong Sanatorium and Hospital, Dr. Ellen Li Charitable Foundation, the Kerry Group Kuok Foundation Limited and Health and Medical Research Fund (1123176).

\section{References}

1. GLOBOCAN 2012: Estimated cancer incidence, mortality and prevalence worldwide in 2012. Available from: http://
globocan.iarc.fr/Pages/fact_sheets_cancer.aspx. Accessed Jan 2016.

2. Carroll JC, Cremin C, Allanson J, et al. Hereditary breast and ovarian cancers. Cab Fam Physician 2008;54:1691-2.

3. Daly MB, Axilbund JE, Buys S, et al. Genetic/familial highrisk assessment: breast and ovarian. J Natl Compr Canc Netw 2010;8:562-94.

4. Claus EB, Schildkraut JM, Thompson WD, Risch NJ. The genetic attributable risk of breast and ovarian cancer. Cancer 1996;77:2318-24.

5. Pharoah PD, Antoniou A, Bobrow M, Zimmern RL, Easton DF, Ponder BA. Polygenic susceptibility to breast cancer and implications for prevention. Nat Genet 2002;31:33-6.

6. Whittemore AS, Gong G, Itnyre J. Prevalence and contribution of BRCA1 mutations in breast cancer and ovarian cancer: results from three U.S. population-based case-control studies of ovarian cancer. Am J Hum Genet 1997;60:496-504.

7. Peng S, Lü B, Ruan W, Zhu Y, Sheng H, Lai M. Genetic polymorphisms and breast cancer risk: evidence from meta-analyses, pooled analyses, and genome-wide association studies. Breast Cancer Res Treat 2011;127:30924.

8. Hall JM, Lee MK, Newman B, et al. Linkage of early-onset familial breast cancer to chromosome 17q21. Science 1990;250:1684-9.

9. Wooster R, Neuhausen SL, Mangion J, et al. Localization of a breast cancer susceptibility gene, $B R C A 2$, to chromosome 13q12-13. Science 1994;265:2088-90.

10. Chen S, Parmigiani G. Meta-analysis of $B R C A 1$ and $B R C A 2$ penetrance. J Clin Oncol 2007;25:1329-33.

11. Mavaddat N, Peock S, Frost D, et al. Cancer risks for $B R C A 1$ and $B R C A 2$ mutation carriers: results from prospective analysis of EMBRACE. J Natl Cancer Inst 2013;105:812-22.

12. Ford D, Easton DF, Stratton M, et al. Genetic heterogeneity and penetrance analysis of the BRCA1 and BRCA2 genes in breast cancer families. The Breast Cancer Linkage Consortium. Am J Human Genet 1998;62:676-89.

13. Antoniou A, Pharoah PD, Narod S, et al. Average risks of breast and ovarian cancer associated with $B R C A 1$ or $B R C A 2$ mutations detected in case series unselected for family history: a combined analysis of 22 studies. Am J Hum Genet 2003;72:1117-30.

14. King MC, Marks JH, Mandell JB; New York Breast Cancer Study Group. Breast and ovarian cancer risks due to inherited mutations in BRCA1 and BRCA2. Science 2003;302:643-6.

15. Graeser MK, Engel $C$, Rhiem K, et al. Contralateral breast cancer risk in BRCA1 and BRCA2 mutation carriers. J Clin Oncol 2009;27:5887-92.

16. Atchley DP, Albarracin CT, Lopez A, et al. Clinical and pathologic characteristics of patients with $B R C A$ positive and $B R C A$-negative breast cancer. J Clin Oncol 2008;26:4282-8.

17. Lakhani SR, Reis-Filho JS, Fulford L, et al. Prediction of $B R C A 1$ status in patients with breast cancer using estrogen receptor and basal phenotype. Clin Cancer Res 2005;11:5175-80.

18. Eerola H, Heikkilä P, Tamminen A, Aittomäki K, Blomqvist C, Nevanlinna H. Histopathological features of breast tumours in BRCA1, BRCA2 and mutation-negative breast cancer families. Breast Cancer Res 2005;7:R93-100.

19. Genetic/Familial High-Risk Assessment: Breast and 
Ovarian 2016. Available from: http://www.nccn.org/ professionals/physician_gls/pdf/genetics_screening.pdf. Accessed Mar 2016.

20. Susman E. Metastatic TNBC: No improvement with carboplatin compared with docetaxel-study did, however, show importance of molecular testing to identify responsive subsets. Oncology Times 2015;37:42-3.

21. Tutt A, Robson M, Garber JE, et al. Oral poly(ADP-ribose) polymerase inhibitor olaparib in patients with $B R C A 1$ or $B R C A 2$ mutations and advanced breast cancer: a proof-ofconcept trial. Lancet 2010;376:235-44.

22. Audeh MW, Carmichael J, Penson RT, et al. Oral poly(ADPribose) polymerase inhibitor olaparib in patients with $B R C A 1$ or BRCA2 mutations and recurrent ovarian cancer: a proof-of-concept trial. Lancet 2010;376:245-51.

23. Diller L, Kassel J, Nelson CE, et al. p53 functions as a cell cycle control protein in osteosarcomas. Mol Cell Biol 1990;10:5772-81.

24. Serrano M, Lin AW, McCurrach ME, Beach D, Lowe SW. Oncogenic ras provokes premature cell senescence associated with accumulation of $p 53$ and p16INK4a. Cell 1997;88:593-602.

25. Shaw P, Bovey R, Tardy S, Sahli R, Sordat B, Costa J. Induction of apoptosis by wild-type $p 53$ in a human colon tumor-derived cell line. Proc Natl Acad Sci U S A 1992;89:4495-9.

26. Vousden KH, Ryan KM. p53 and metabolism. Nat Rev Cancer 2009;9:691-700.

27. Wang PY, Ma W, Park JY, et al. Increased oxidative metabolism in the Li-Fraumeni syndrome. N Engl J Med 2013;368:1027-32.

28. Wang Y, Blandino G, Oren M, Givol D. Induced p53 expression in lung cancer cell line promotes cell senescence and differentially modifies the cytotoxicity of anti-cancer drugs. Oncogene 1998;17:1923-30.

29. Li FP, Fraumeni JF Jr. Soft-tissue sarcomas, breast cancer, and other neoplasms. A familial syndrome? Ann Intern Med 1969;71:747-52.

30. Li FP, Fraumeni JF Jr, Mulvihill JJ, et al. A cancer family syndrome in twenty-four kindreds. Cancer Res 1988;48:5358-62.

31. McCuaig JM, Armel SR, Novokmet A, et al. Routine TP53 testing for breast cancer under age 30: ready for prime time? Fam Cancer 2012;11:607-13.

32. Sidransky D, Tokino T, Helzlsouer $\mathrm{K}$, et al. Inherited $p 53$ gene mutations in breast cancer. Cancer Res 1992;52:29846.

33. Birch JM, Blair V, Kelsey AM, et al. Cancer phenotype correlates with constitutional TP53 genotype in families with the Li-Fraumeni syndrome. Oncogene 1998;17:10618.

34. Olivier M, Goldgar DE, Sodha N, et al. Li-Fraumeni and related syndromes: correlation between tumor type, family structure, and TP53 genotype. Cancer Res 2003;63:664350.

35. Walsh T, Casadei S, Coats $\mathrm{KH}$, et al. Spectrum of mutations in BRCA1, BRCA2, CHEK2, and TP53 in families at high risk of breast cancer. JAMA 2006;295:1379-88.

36. Masciari S, Dillon DA, Rath $M$, et al. Breast cancer phenotype in women with TP53 germline mutations: a LiFraumeni syndrome consortium effort. Breast Cancer Res Treat 2012;133:1125-30.

37. Melhem-Bertrandt A, Bojadzieva J, Ready KJ, et al. Early onset HER2-positive breast cancer is associated with germline TP53 mutations. Cancer 2012;118:908-13.

38. Wilson JR, Bateman AC, Hanson H, et al. A novel HER2positive breast cancer phenotype arising from germline TP53 mutations. J Med Genet 2010;47:771-4.

39. Lalloo F, Varley J, Moran A, et al. BRCA1, BRCA2 and TP53 mutations in very early-onset breast cancer with associated risks to relatives. Eur J Cancer 2006;42:1143-50.

40. Mouchawar J, Korch C, Byers T, et al. Population-based estimate of the contribution of TP53 mutations to subgroups of early-onset breast cancer: Australian Breast Cancer Family Study. Cancer Res 2010;70:4795-800.

41. Varley JM. Germline TP53 mutations and Li-Fraumeni syndrome. Hum Mutat 2003;21:313-20.

42. Birch JM, Hartley AL, Tricker KJ, et al. Prevalence and diversity of constitutional mutations in the $p 53$ gene among 21 Li-Fraumeni families. Cancer Res 1994;54:1298-304.

43. Shen WH, Balajee AS, Wang J, et al. Essential role for nuclear PTEN in maintaining chromosomal integrity. Cell 2007;128:157-70.

44. Hanssen AM, Fryns JP. Cowden syndrome. J Med Genet 1995;32:117-9.

45. Tan MH, Mester JL, Ngeow J, Rybicki LA, Orloff MS, Eng C. Lifetime cancer risks in individuals with germline PTEN mutations. Clin Cancer Res 2012;18:400-7.

46. Pilarski R. Cowden syndrome: a critical review of the clinical literature. J Genet Couns 2009;18:13-27.

47. Schrager CA, Schneider D, Gruener AC, Tsou HC, Peacocke M. Similarities of cutaneous and breast pathology in Cowden's Syndrome. Exp Dermatol 1998;7:380-90.

48. Schrager CA, Schneider D, Gruener AC, Tsou HC, Peacocke M. Clinical and pathological features of breast disease in Cowden's syndrome: an underrecognized syndrome with an increased risk of breast cancer. Hum Pathol 1998;29:47-53.

49. Starink TM, van der Veen JP, Arwert F, et al. The Cowden syndrome: a clinical and genetic study in 21 patients. Clin Genet 1986;29:222-33.

50. Xia B, Sheng Q, Nakanishi K, et al. Control of BRCA2 cellular and clinical functions by a nuclear partner, $P A L B 2$. Mol Cell 2006;22:719-29.

51. Sy SM, Huen MS, Zhu Y, Chen J. PALB2 regulates recombinational repair through chromatin association and oligomerization. J Biol Chem 2009;284:18302-10.

52. Tischkowitz M, Xia B. PALB2/FANCN: recombining cancer and Fanconi anemia. Cancer Res 2010;70:7353-9.

53. Casadei S, Norquist BM, Walsh T, et al. Contribution of inherited mutations in the BRCA2-interacting protein PALB2 to familial breast cancer. Cancer Res 2011;71:22229.

54. Erkko H, Xia B, Nikkilä J, et al. A recurrent mutation in PALB2 in Finnish cancer families. Nature 2007;446:316-9.

55. Lee AS, Ang P. Breast-cancer risk in families with mutations in PALB2. N Engl J Med 2014;371:1650-1.

56. Antoniou AC, Casadei S, Heikkinen T, et al. Breast-cancer risk in families with mutations in $P A L B 2$. N Engl J Med 2014;371:497-506.

57. Fitzgerald RC, Hardwick R, Huntsman D, et al. Hereditary diffuse gastric cancer: updated consensus guidelines for clinical management and directions for future research. J Med Genet 2010;47:436-44.

58. Hearle N, Schumacher V, Menko FH, et al. Frequency and spectrum of cancers in the Peutz-Jeghers syndrome. Clin 
Cancer Res 2006;12:3209-15.

59. Win AK, Young JP, Lindor NM, et al. Colorectal and other cancer risks for carriers and noncarriers from families with a DNA mismatch repair gene mutation: a prospective cohort study. J Clin Oncol 2012;30:958-64.

60. Economopoulou P, Dimitriadis G, Psyrri A. Beyond BRCA: new hereditary breast cancer susceptibility genes. Cancer Treat Rev 2015;41:1-8.

61. Bennett KL, Mester J, Eng C. Germline epigenetic regulation of KILLIN in Cowden and Cowden-like syndrome. JAMA 2010;304:2724-31.

62. Hobert JA, Eng C. PTEN hamartoma tumor syndrome: an overview. Genet Med 2009;11:687-94.

63. Lim W, Hearle N, Shah B, et al. Further observations on LKB1/STK11 status and cancer risk in Peutz-Jeghers syndrome. Br J Cancer 2003;89:308-13.

64. McGarrity TJ, Amos CI, Frazier ML, Wei C. PeutzJeghers syndrome. In: Pagon RA, Adam MP, Ardinger $\mathrm{HH}$, et al, editors. GeneReviews [internet]. Seattle (WA): GeneReviews(R); 1993.

65. Pharoah PD, Guilford P, Caldas C; International Gastric Cancer Linkage Consortium. Incidence of gastric cancer and breast cancer in CDH1 (E-cadherin) mutation carriers from hereditary diffuse gastric cancer families. Gastroenterology 2001;121:1348-53.

66. Kaurah P, MacMillan A, Boyd N, et al. Founder and recurrent $C D H 1$ mutations in families with hereditary diffuse gastric cancer. JAMA 2007;297:2360-72.

67. Renwick A, Thompson D, Seal S, et al. ATM mutations that cause ataxia-telangiectasia are breast cancer susceptibility alleles. Nat Genet 2006;38:873-5.
68. Thompson D, Duedal S, Kirner J, et al. Cancer risks and mortality in heterozygous ATM mutation carriers. J Natl Cancer Inst 2005;97:813-22.

69. Ahmed M, Rahman N. ATM and breast cancer susceptibility. Oncogene 2006;25:5906-11.

70. Roberts NJ, Jiao Y, Yu J, et al. ATM mutations in patients with hereditary pancreatic cancer. Cancer Discov 2012;2:41-6.

71. Meijers-Heijboer H, van den Ouweland A, Klijn J, et al. Low-penetrance susceptibility to breast cancer due to CHEK2 $2(*) 1100$ delC in noncarriers of BRCA1 or BRCA2 mutations. Nat Genet 2002;31:55-9.

72. Narod SA. Testing for CHEK2 in the cancer genetics clinic: ready for prime time? Clin Genet 2010;78:1-7.

73. Weischer M, Bojesen SE, Ellervik C, Tybjaerg-Hansen A, Nordestgaard BG. CHEK2*1100delC genotyping for clinical assessment of breast cancer risk: meta-analyses of 26,000 patient cases and 27,000 controls. J Clin Oncol 2008;26:542-8

74. Cybulski C, Wokołorczyk D, Jakubowska A, et al. Risk of breast cancer in women with a CHEK2 mutation with and without a family history of breast cancer. J Clin Oncol 2011;29:3747-52.

75. Kwong A, Chen J, Shin VY, et al. The importance of analysis of long-range rearrangement of BRCA1 and BRCA2 in genetic diagnosis of familial breast cancer. Cancer Genet 2015;208:448-54

76. McCourt CM, McArt DG, Mills K, et al. Validation of next generation sequencing technologies in comparison to current diagnostic gold standards for $B R A F, E G F R$ and KRAS mutational analysis. PloS One 2013;8:e69604. 